\title{
Relationship Between Attitudes toward E-Learning Method and Learning Achievement in English Language Study Program Students at FKIP UMSU
}

\author{
Ratna Sari Dewi ${ }^{1}$, Selamat Husni Hasibuan ${ }^{2}$ \\ ${ }^{1,2}$ University of Muhammadiyah Sumatera Utara, Medan, Indonesia
}

\begin{abstract}
The purpose of this study was to determine the relationship between student attitudes towards the E-Learning method and the learning achievement of English Language Education students at North Sumatra Muhammadiyah University. This research was conducted at UMSU with the subject of English Language Education Semester VIII. Data collection in this study was conducted using a questionnaire and documentation study. Questionnaires are used to collect data on student attitudes in online learning, while documentation studies are used to collect data on student learning outcomes. The technique used in this study is to test the validity and reliability. Data processing techniques use the SPSS version 20 program by carrying out tests of normality and linearity. The results of the linearity test at a significance level of $0.007<0.05$ which indicates the relationship between the attitude of e-learning learning and learning achievement is linear. between the attitude of students towards ELearning learning with learning achievement in the English study program UMSU.
\end{abstract}

Keywords : attitudes, learning achievements, E-Learning

\section{Introduction}

One way to improve the quality of learning is to provide information technology-based facilities known as E-Learning. E-Learning is defined as a learning method facilitated and supported by an information technology-based system. The emphasis remains on the learning process and not technology. On this basis E-learning can also be referred to as a distance learning system (not distant class) cannot replace teaching staff, but together with existing learning methods can improve the quality and purpose of learning (Towards a Unified ELearning Strategy, DFES 2003).

In general, each E-Learning method must have advantages and disadvantages, including the E-Learning method. Some of the advantages possessed by the E-Learning method include the availability of e-moderating facilities that make it easier for students and teachers to communicate without space and time constraints, structured and scheduled teaching materials for students and can be reviewed at any time and at any time, changing student roles from passive to active. While a number of shortcomings of the E-Learning method include: students and instructors lacking interaction, tend to ignore academic and social aspects, encourage the growth of business aspects, low motivated students tend to fail, lack of internet facilities and mastery of internet skills.

As a University that also has a mission to improve the quality of education, UMSU does not want to miss out on its participation. For this reason, starting in 2018 UMSU has established an information technology-based learning method. In order to support the smooth implementation of this method, the campus has provided sufficient facilities in class 2018 . Through this method, students are required to view or access lecture material and complete lecture assignments through the internet, either through computers on campus or personal computers. The application of this method is likely to lead to positive and negative attitudes among UMSU students. 
Students who are positive about this method feel that the method is more effective and efficient for themselves in completing the lectures they carry out. This is because students can attend lecture material and assignments given by lecturers whenever and wherever they can access data. not only on campus but they can access it in internet cafes, at home and elsewhere. Meanwhile for students who think negatively, consider that this method must be supported by complete information technology technology. In addition, students are required to have the knowledge and skills to operate the technology. And for students who do not have the funds and skills in operating technology, they will encounter many obstacles in their learning process.

\section{Literature Review}

\section{Attitude}

Attitude is a reaction or response of someone who is still closed to a stimulus or object (Soekidjo N, 2003). Newcomb in Notoatmodjo (2003) states that attitude is readiness or willingness to act, and is not an implementation of certain motives. Attitude is not an action or activity, but is a "pre-disposition" of actions or behavior. Attitude is still a closed reaction, not an open reaction.

Attitude is a form of evaluation / reaction to an object, impartial / impartial which is a certain order in terms of feelings (affection), thought (cognition) and predisposition of action (konasi) someone towards an aspect in the surrounding environment (Saifudin A, 2005).

\section{Attitude Component}

According to Azwar (2005), the components of attitude are:

1. Cognitive

Cognitive is formed from knowledge and information received which is then processed to produce a decision to act.

2. Affective

Regarding the subjective social emotional problem of an object, in general this component is equated with the feeling that is owned by an object.

3. Conative

Demonstrate how behavior or tendency to behave in a person is related to the object of the attitude he is facing.

\section{Level of attitude}

Various levels according to Notoatmodjo (2003) consist of:

1. Receiving

Receiving means that people (subjects) want and pay attention to the stimulus given (object).

2. Responding

Providing answers when asked, doing something and completing a given assignment is an indication of attitude.

3. Respect (Valuting)

Inviting other people to work on / discuss a problem is an indication of attitude.

4. Responsible

Being responsible for everything he has chosen with all risks is the highest attitude.

According to Heri Purwanto (1998) 
(a) Positive attitude, the tendency of action is to approach, like and expect certain objects.

(b) Negative attitudes, there is a tendency to stay away from, avoid, hate and dislike certain objects.

\subsection{E-Learning Methods}

(Michael, 2013: 27) E-learning is compiled learning with the aim of using an electronic system or computer so that it is able to support a learning process.

(Chandrawati, 2010) E-learning is a process of distance learning by combining principles in the process of learning with technology.

(Ardiansyah, 2013) E-learning is a learning system that is used as a means is as a teaching and learning process carried out without having to meet face to face directly between educators and students.

\section{Characteristics of E-learning}

According to Rosenberg (2001) the characteristics of E-learning are networked, which makes it able to be able to improve quickly, save or also bring back, distribute, and also share learning and information.

Characteristics of E-learning according to Nursalam (2008: 135) include:

- Using self-learning materials which are then stored on the computer, so that they can be accessed by students and students anytime and anywhere.

- Utilizing a learning schedule, curriculum, learning progress results, and things related to an educational administration can be seen on each computer.

- Use an electronic technology service.

- Utilizing a superiority of computers (digital media as well as computer networks)

\section{Benefits of E-learning}

The benefits of E-learning include the following:

- Cost Efficiency.

- E-learning provides cost efficiency for the administration of its administration, the efficiency of providing facilities as well as physical facilities to be able to learn and also cost efficiency for learners are the costs of transportation and accommodation.

- Flexible.

- Learn to be independent.

- E-learning provides opportunities for learners to independently hold all control of success in the learning process.

The benefits of E-learning according to Pranoto, et al (2009: 309) include the following:

- Increase an active participation from students.

- Improve a student's independent learning ability.

- Improving an educator's material quality as well as training.

- Improve an ability to be able to display information with information technology devices, which with ordinary devices will be difficult. 


\section{The advantages of E-learning}

The advantages of E-learning are providing flexibility, interactivity, speed, visualization through various advantages of each media (Sujana, 2005: 253). According to L. Tjokro (2009: 187), E-learning has many advantages, namely:

- It is easier to absorb, meaning that it uses multimedia facilities in the form of images, text, animation, sound, and also videos.

- Much more effective in costs, meaning that there is no need for an instructor, no need for a minimum audience, anywhere, and so on

- Much more concise, meaning that it does not contain a lot of class formalities, directly into a subject, subjects that fit your needs.

- Available in 24 hours per day, meaning that penguasaan in the material depends on enthusiasm and also the absorption of students, can be monitored, can be tested by etest.

\section{Lack of E-learning}

According to L. Gavrilova (2006: 354) Deficiency of E-learning is a learning using the E-learning model that requires more additional equipment (such as computers, monitors, keyboards, etc.).

The disadvantages of E-learning described by Nursalam (2008: 140) include the following:

- Lack of interaction between the teacher and the student or even between the students themselves.

- This tendency can ignore academic aspects as well as social aspects and vice versa make the growth of aspects of business or also commercial.

- The teaching and learning process tends towards a training rather than education itself.

- Changes in a teaching role from those who initially mastered conventional learning techniques, are now also required to be able to know learning techniques using ICT (information, communication, and also technology).

- Not all internet facilities are available at all places

- These students may be frustrated if they cannot access graphics, images, and videos due to inadequate equipment (software and hardware).

\subsection{Learning Achievement}

According to Siti Partini (1980: 49), "Learning Achievement is the result achieved by someone in learning activities". In line with the opinion achieved by someone in learning activities ". In line with that opinion Sunarya (1983: 4) states "Learning Achievement is a change in behavior that covers cognitive, affective, and psychomotor domains which is a measure of student success". Haditomo et al (1980: 4), said "Learning Achievement is a person's ability Dewa Ketut Sukardi (1983: 51), states" To measure Learning Achievement using the achievement test which is intended as a tool to reveal actual abilities as a result of learning or learning ". According to Sumadi Suryabrata (1987: 324), "Value is the last formulation that can be given by the teacher to fund the progress or student achievement during a certain period". With report cards, we can find out student achievement. Students with good report cards are said to have high achievements, while those with poor grades are said to be of low learning achievement. 
From some of the opinions above, it can be concluded that learning achievement is a success that can be achieved by students which can be seen from the knowledge, attitudes, and expertise they have.

\section{Factors Affecting Learning Achievement}

Every activity carried out by someone certainly has factors that influence it, both of which tend to encourage or inhibit. Likewise experienced in learning. Ahmadi, (in Yulita, 2008) states there are several factors that influence student achievement, including:

\section{1) Internal Factors}

Internal factors are factors that come from within students, which consist of:

a) Intelligence factor

In the narrow sense of intelligence can be interpreted as the ability to achieve achievement. Intelligence plays an important role in achieving achievement.

b) Interest factors Interest is a strong tendency in a person to feel attracted to something.

c) Factors of physical and psychological conditions Physical conditions related to the state of growth, physical health, state of the sense organs and so on. The psychological state is related to the mental state of the student.

\section{2) External Factors}

External factors are factors outside of the learners who influence learning achievement. There are several external factors, namely:

a) Teacher Factors The teacher is tasked with guiding, training, processing, researching, developing and organizing teaching and learning activities.

b) Family environment factors

The family is very influential on the progress of learning achievement, because most of the time students have at home. So, there are many opportunities to study at home. The involvement of parents deserves to be taken into account in an effort to maintain the motivation to learn students. In a study of learning achievement, a strong relationship was found between parental involvement and learning achievement (Haster in Suwatra 2007).

\section{Learning source factors}

Learning resources can be in the form of media or learning aids and supporting book materials. Learning aids are all tools that can be used to help students in learning. Learning will be more interesting, concrete, easy to understand, save time and energy and the results are more meaningful.

\section{Methodology}

This study uses a quantitative descriptive method. The Likert scale is used to measure student attitudes towards the use of E-Learning. In research, the scale is used to assess attitudes desired by researchers by submitting a number of statements to respondents. Then the respondents were asked to give choices on the measuring scale provided.

Data collection in this study was conducted using a questionnaire and documentation study. Questionnaires are used to collect data on student attitudes in online learning, while documentation studies are used to collect data on student learning outcomes. The techniques 
used in this study are validity and reliability. The validity of a test is related to what is measured by the test and how well the test measures it (Anastasi \& Urbina, 2003). Calculation of validity uses construct validity with the Pearson's product moment correlation formula.

Data processing is also done using SPSS version 20, a computer program to calculate statistical values consisting of:

1. Testing data normality, testing normality using lifefors test provided that if the results of the Lhitung analysis $<\mathrm{L}$ table then Ho is accepted which means the sample is normal distribution, while homogeneity testing using the Barlett test provided that the X2 analysis results $<\mathrm{X} 2$ table then Ho is accepted which means the grouping of variables over X1 has homogeneous variance.

2. Y linearity test with $\mathrm{x}$ provided that if Fcount $<\mathrm{F}$ table then linear regression equation.

3. Correlation Analysis

\section{Correlation Test}

\section{Pearson Product Correlation Analysis}

Used to find out how closely the relationship between independent variables and the dependent variable. In general, significant values of correlation are:

a. If a significant value $<0.05$ is correlated

b. If the significant value $>0.05$ is not correlated

The degree of Pearson Product Moment correlation is as follows:

1. Value 0,00 to 0,20 there is no correlation

2. Value of 0.21 to 0.40 weak correlation

3. Value 0.41 up to 0.60 medium correlation

4. Value of 0.61 to 0.80 strong correlation

5. The value of 0.81 to 1.00 is perfect correlation

\section{Research Results and Discussion}

In the results of this study and discussion will be explained sequentially about the description of the data, the test for normality and linearity and the discussion of the results of the study.

\section{A. Data Description}

\section{Student Learning Outcomes}

Table 4.1 Frequency Distribution of Learning Achievements for Undergraduate Students of English Education in Semester 8 FKIP UMSU 2015

\begin{tabular}{|l|r|}
\hline $\mathrm{N} \quad$ Valid & 30 \\
Mean & Missing \\
Median & 75.7667 \\
Minimum & 76.0000 \\
Maximum & 72.00 \\
& 80.00 \\
\hline
\end{tabular}




\begin{tabular}{|r|r|r|r|r|}
\hline & Frequency & Percent & $\begin{array}{c}\text { Valid } \\
\text { Percent }\end{array}$ & $\begin{array}{c}\text { Cumulative } \\
\text { Percent }\end{array}$ \\
\hline 72.00 & 1 & 3.3 & 3.3 & 3.3 \\
73.00 & 2 & 6.7 & 6.7 & 10.0 \\
74.00 & 3 & 10.0 & 10.0 & 20.0 \\
75.00 & 8 & 26.7 & 26.7 & 46.7 \\
Valid 76.00 & 8 & 26.7 & 26.7 & 73.3 \\
77.00 & 3 & 10.0 & 10.0 & 83.3 \\
78.00 & 3 & 10.0 & 10.0 & 93.3 \\
80.00 & 2 & 6.7 & 6.7 & 100.0 \\
Total & 30 & 100.0 & 100.0 & \\
\hline
\end{tabular}

Table 4.1 shows that the mean value of student learning outcomes is 75.77 , median score is 76 , minimum score is 72 and maximum value is 80 . From the overall sample, students who get the highest score are 2 students $(6.7 \%)$ and those who get the minimum score 1 student (3.3\%). And the highest percentage of student learning outcomes is in the values of 75 and 76 , each of which is 8 students $(26.7 \%)$.

\section{Student Attitudes toward E-Learning}

Table 4.2 Frequency Distribution of Attitudes Towards E-Learning

\begin{tabular}{|c|c|c|c|c|c|c|c|c|}
\hline No & \multicolumn{2}{|c|}{ Acsess } & \multicolumn{2}{c|}{ Interaction } & \multicolumn{2}{c|}{ Respond } & \multicolumn{2}{c|}{ Achievement } \\
\hline & Highest & lowest & highest & lowest & Highest & lowest & highest & lowest \\
\hline 1 & 17 & 1 & 13 & 3 & 14 & 6 & 19 & 1 \\
\hline
\end{tabular}

From table 4.2 it can be seen that the highest average question about access to e-learning with an attitude of agreeing as much as 17 respondents $(56.7 \%)$ while the least with the attitude not very agree as much as 1 respondent $(3.3 \%)$.

The question of the attitude of interaction in e-learning has the highest average with an attitude of agreement as much as 13 respondents (43.3\%) while the lowest with a very disagreeable attitude as many as 3 respondents (10\%).

The question of e-learning response attitudes has the highest average score of 14 respondents $(46.7 \%)$ while the lowest with a strongly disagree attitude is 6 respondents $(20 \%)$.

Questions about achievement in e-learning have the highest average with an attitude of agreeing as many as 19 respondents $(63.3 \%)$ while the lowest with a very disagreeable attitude as much as 1 respondent $(3.3 \%)$.

\section{B. Testing Data Analysis Requirements \\ 1. Normality Test}

Normality testing uses the Shapiro Wilk test. The results of the normality test are presented in the following table 4.3:

Table 4.3 Summary of the Normality Test of Learning Outcomes (y) with student attitudes toward E-Learning (x)

\begin{tabular}{|l|l|l|l|l|}
\hline No & Variable & \multicolumn{1}{c|}{ Lhitung } & \multicolumn{1}{c|}{ Ltable $_{\text {Conclusion }}$} \\
\hline 1 & $\mathrm{Y}$ & 0,198 & 0,05 & Normal \\
\hline 2 & $\mathrm{X}$ & 0,340 & 0,05 & Normal \\
\hline
\end{tabular}


Information:

Y: Student Learning Outcomes

$\mathrm{X}$ : The attitude of learning towards E-Learning

\section{a. Normality Test of Student Learning Results}

Based on table 4.3, the results of the calculation of the normality test obtained with $n$ $=30$, significance level $\alpha=0.05$, then the value of liliefors count $(\mathrm{Lo})=0.198$, while the price of Liliefors table $(\mathrm{Lt})=0.05$. Thus Lo $<\mathrm{Lt}$ so Ho is accepted. The conclusion is a sample of student learning outcomes data originating from a population with normal distribution.

\section{b. Data Normality Test Attitudes towards E-Learning learning}

Based on the results of the calculation of the normality test with $n=30$, the significance level $\alpha=0.05$, then the price of the liliefors count (Lo) $=0.340$, while the price of the Liliefors table $(\mathrm{Lt})=0.05$. Thus Lo $<\mathrm{Lt}$ so Ho is accepted. The conclusion is the sample data on student attitudes derived from the population with normal distribution.

\section{Learning Outcomes Linearity Test on Attitude}

Table 4.4 Summary of the results of the Learning Outcomes Linearity Test on Attitude

\begin{tabular}{|l|l|l|l|l|}
\hline No & \multicolumn{1}{|c|}{ Nilai } & \multicolumn{1}{|c|}{ L $_{\text {hitung }}$} & \multicolumn{1}{c|}{ L $_{\text {tabel }}$} & Kesimpulan \\
\hline 1 & $\begin{array}{l}\text { Deviation from } \\
\text { linearity }\end{array}$ & 0,700 & 0,05 & Linear \\
\hline 2 & linearity & 0,007 & 0,05 & Linear \\
\hline
\end{tabular}

From the calculation of the linearity test of the regression line equation Table 4.4 is obtained from the line deviation of linearity (Deviation from linearity), namely Fcount $=0,700$ with $p$-value $=>0,05$, and linearity $0,007<0,05$; this means that Ho is accepted or the learning outcome regression equation for the attitude of E-Learning is linear or in the form of a linear line. In other words there is a relationship between student learning outcomes and learning attitudes towards E-Learning.

\section{Pearson Product Moment Test}

Table 4.5 Pearson Correlation

\begin{tabular}{|cc|c|c|}
\hline & & Attitude & $\begin{array}{c}\text { Learning } \\
\text { Outcomes }\end{array}$ \\
\hline Attitude & Pearson Correlation & 1 & $.551^{* *}$ \\
& Sig. (2-tailed) & & .002 \\
Learning & Pearson Correlation & $.551^{* *}$ & 30 \\
Outcomes & Sig. (2-tailed) & .002 & 1 \\
& $\mathrm{~N}$ & 30 & 30 \\
\hline
\end{tabular}

**. Correlation is significant at the 0.01 level (2-tailed).

To find out the relationship between attitudes toward E-Learning and learning achievement used the Pearson Product Moment test. Table 4.5 shows the results of Pearson 
Product Moment obtained a significance level of $\alpha=0.002<0.05$ and the value of Pearson Product Moment of 0.551 which means there is a relationship between attitudes toward elearning learning and student achievement with degrees of relationship included in the medium correlation.

\section{Conclusions and Suggestions}

\section{Conclusions}

Based on the results of the research data, it can be concluded that there is a relationship that occurs between attitudes towards e-learning and student achievement in English study programs. Some of the results of the research conducted are as follows:

1. Students show a positive attitude towards e-learning in the learning process.

2. There is a relationship with a moderate correlation degree with a significance level of $\alpha=0.002<0.05$ and Pearson Product Moment test results of 0.551 which means there is a relationship between attitudes towards e-learning and student learning achievement.

\section{Suggestions}

Based on the conclusions that have been presented, the authors propose several suggestions as follows:

1. The need to further enhance e-learning in the future to students to further improve their learning achievement.

2. Need further research on the findings of this research with different objects and subjects.

\section{References}

2013. Prosedure Penelitian Suatu Pendekatan Praktik. Jakarta: Penerbit Rineka Cipta.

Cunningham, Josh. 2012. Student Achievement. Washington:National Conference of State Legislatures

Johnson, Woodcock. 2001. Tests of Achievement. Nelson Education: Riverside Publishing

Bevan, N. 2009. International Standards for Usability Should be more Widely Used. Journal of Usability Studies, 4(3), 106-113.

Cercone, K . 2008 . Characteristics of adult learners with implications for online learning design, AACE Journal, 16 (2), 137-159.

Dimyati dan Mudhiono. 2006 . Belajar dan Pembelajaran. Jakarta: PT Rineka Cipta.

Saifudin, Azwar. 2005. Sikap Manusia. Yogyakarta: Pustaka Belajar.

Allen, Michael. 2013. Michael Allen's Guide to E-learning. Canada : John Wiley \& Sons.

Ardiansyah, Ivan. 2013. Eksplorasi Pola Komunikasi dalam Diskusi Menggunakan Moddle pada Perkuliahan Simulasi Pembelajaran Kimia, Universitas Pendidikan Indonesia, Bandung-Indonesia.

Chandrawati, Sri Rahayu. 2010. Pemanfaatan E-learning dalam Pembelajaran. No 2 Vol. 8. http://jurnal.untan.ac.id 